\title{
Pharmacokinetics of placental protein 13 after intravenous and subcutaneous administration in rabbits
}

This article was published in the following Dove Press journal:

Drug Design, Development and Therapy

\section{Tijana Drobnjak' \\ Hamutal Meiri ${ }^{2,3}$ \\ Maurizio Mandalá ${ }^{4}$ \\ Berthold Huppertz ${ }^{5}$ \\ Sveinbjörn Gizurarson'}

'Faculty of Pharmaceutical Sciences, School of Health Sciences, University of Iceland, Reykjavik, Iceland; ${ }^{2} \mathrm{Hy}$ Laboratories, Rehovot, Israel;

${ }^{3}$ TeleMarpe Ltd., Tel Aviv, Israel;

${ }^{4}$ Department of Biology, Ecology and Earth Sciences, University of Calabria, Rende, Italy; ${ }^{5}$ Department of Cell Biology, Histology and Embryology, Gottfried Schatz Research Center, Medical University of Graz, Graz, Austria
Correspondence: Sveinbjörn Gizurarson Faculty of Pharmaceutical Sciences, School of Health Sciences, University of Iceland, Hofsvallagata 53,

107 Reykjavik, Iceland

Tel +35489803I8

Email sveinbj@hi.is
Introduction: Human placental protein 13 (PP13) is a galectin predominantly expressed by the placenta. Low serum concentrations of PP13 in early pregnancy indicate a higher risk of developing preeclampsia.

Methods: The pharmacokinetic disposition and bioavailability of PP13 were determined by single intravenous and subcutaneous administration to 12 healthy New Zealand White rabbits. The serum pharmacokinetic values were determined by enzyme-linked immunosorbent assay, and are best described by a two-compartment model.

Results: Both volume of distribution and the area under the curve were dose dependent for the intravenous group $(p<0.01)$. PP13 elimination half-life was also found to be different between the groups $(p<0.01)$. The bioavailability of PP13 following subcutaneous administration was found to be $57 \%$.

Conclusion: This study shows that the concentration of total PP13 released into the maternal circulation during pregnancy might be much higher than previously estimated.

Keywords: PP13, ELISA, PK, eNOS, prostaglandin, preeclampsia

\section{Introduction}

Human placental protein 13 (PP13) is a member of placentally expressed proteins and of $\beta$-galactoside-binding proteins or galectins. ${ }^{1,2}$ PP13 was first isolated in 1983 by Bohn from human placenta ${ }^{3}$ and is predominantly expressed in this organ; ${ }^{4}$ however, Than et al have reported its presence in rare tumors of fetal spleen and liver tissues as well. ${ }^{1}$ Several studies in humans have shown that low PP13 levels in maternal serum early in pregnancy are associated with the subsequent development of preeclampsia, 5,6 an obstetrical complication affecting around $2 \%-5 \%$ of all pregnancies and one of the leading causes of maternal and perinatal morbidity and mortality. ${ }^{7,8}$ Preeclampsia is a disorder characterized by a constellation of signs and symptoms, eminently new onset of hypertension and proteinuria developed from the midst of pregnancy in previously normotensive women with no such symptoms. ${ }^{7,8}$ Later in life, the disorder can increase the frequency of developing cardiovascular diseases in women with a history of preeclampsia. ${ }^{9,10}$ Earlier meta-analyses of PP13 across various studies in humans have described a significant decrease in circulating concentrations in early pregnancy in those women developing preeclampsia later in pregnancy. ${ }^{1}$ This decrease might be directly related to the severity of the disorder. Other parameters like ethnic origin, obesity, blood groups, and genetic polymorphism of the protein's primary sequence play a major role in the severity of preeclampsia and especially among women of African origin. ${ }^{6,11-14}$ 
PP13 is secreted from the placental syncytiotrophoblast, and as galectin 13, it shows structural homologies to other members of the galectin family. ${ }^{15}$ It has high affinity for sugar residues and is implied to be involved in conferring immunotolerance of the mother at the site of trophoblast invasion during uterine artery remodeling in early pregnancy in order to enable deep placentation. ${ }^{16-19}$

Studies performed in rats have shown that PP13 decreases blood pressure, ${ }^{20}$ and it has been shown to induce vasodilation of resistance arteries through endothelial signaling involving the pathways of endothelial nitric oxide synthase (eNOS) and prostaglandin. ${ }^{21}$ In rats, PP13 administration results in larger pups and heavier placentas due to a possible increase in blood flow and oxygen supply to the uterine vasculature in pregnancy. It has been suggested that PP13 replenishing in pregnancies with low maternal serum level may assist in preventing preeclampsia. ${ }^{5,12,22}$ Thus, it is important to understand the availability of PP13 administrated externally. The aim of the current study was to determine the kinetic disposition and bioavailability of PP13 in serum after intravenous (IV) and subcutaneous (SC) administration of the protein in healthy rabbits.

\section{Materials and methods}

\section{Animals and ethics approval}

Twelve female nonpregnant New Zealand White (NZW) rabbits were purchased from Envigo (Huntington, UK) and housed at the laboratory animal care facility at the University of Iceland (Reykjavik, Iceland).

The NZW rabbits, each weighing on average $3.9 \pm 0.3 \mathrm{~kg}$, were caged in groups of three with access to food and water ad libitum and maintained on a 12/12 h light/dark cycle.

The study was approved by the Icelandic Animal Ethic Committee (study number: 2015-09-02) and carried out according to the US National Institutes of Health Guide for the Care and Use of Laboratory Animals. All efforts were undertaken according to the "3R principles" (www.nc3rs. org.uk) to reduce the number of animals used in the study and optimize experimental protocols for obtaining maximum data from each tested animal.

\section{Placental protein 13}

Recombinant PP13 without the histidine tag was prepared by expressing the recombinant wild-type PP13 construct in Escherichia coli, harvesting, and purification as was already described, ${ }^{21}$ and its DNA sequence was verified by Sanger sequencing (https://www.ncbi.nlm.nih.gov/pmc/articles/ PMC431765/). The molecular weight and the purity of the protein were verified by sodium dodecyl sulphate polyacrylamide gel electrophoresis, high performance liquid chromatography, and immunoblots with PP13-specific monoclonal antibodies. The concentration was determined using a PP13 enzyme-linked immunosorbent assay (ELISA) kit as previously described. ${ }^{23}$

\section{Experimental procedure}

The animals were divided into four experimental groups ( $n=6 /$ group). Each animal was assigned to one group, allowed to rest for a week, and then allocated to a different experimental group. Three groups received IV injection $(1.3,2.6$, or $12.8 \mathrm{ng} / \mathrm{kg}$ ) of PP13 that was administered into the right marginal ear vein. The fourth group received SC injection $(12.8 \mathrm{ng} / \mathrm{kg})$, administered under the skin, at the neck area on the back.

PP13 was diluted in $0.9 \%$ saline solution at 5,10 , and $50 \mathrm{ng} / \mathrm{mL}$, corresponding to concentrations of 1.3, 2.6, and $12.8 \mathrm{ng} / \mathrm{kg}$, respectively, and was administered as a single IV injection or by SC route (only $12.8 \mathrm{ng} / \mathrm{kg}$ ).

A blood control sample of $\sim 1 \mathrm{~mL}$ was collected from the marginal vein of the left ear (opposite to the administration side) of each animal and stored into serum vacutainer tubes. The blood was collected prior to protein administration $\left(\mathrm{T}_{0}\right)$ and also at a time series of 10, 30, 60, and 90 min and 2, 4, 6, and $24 \mathrm{~h}$ after PP13 administration.

Blood samples were centrifuged within $2 \mathrm{~h}$ after collection, and the separated serum was kept frozen at $-80^{\circ} \mathrm{C}$ until further analysis. The storage at $-80^{\circ} \mathrm{C}$ does not have any impact on PP13 protein stability. ${ }^{24}$

\section{Analytical assay}

PP13 in the serum samples was determined by a commercially available ELISA kit from Cusabio (Wuhan, China; category number: CSB-E12733h). All the samples were analyzed in duplicates. The working range of the assay is from 2.5 to $1,000 \mathrm{pg} / \mathrm{mL}$. Calibration curves had a regression coefficient at $R^{2}>0.99$. Intraassay precision and interassay precision had a coefficient of variance of $10 \%$ and $11 \%$, respectively. Interassay precision was determined by measuring standard samples on three separate days. The calibration curves were fitted with a four-parameter logistic equation.

\section{Pharmacokinetics and statistical analysis}

PP13 serum concentrations of each animal were analyzed over time using GraphPad Prism (GraphPad Software, San Diego, CA, USA). To describe the pharmacokinetics of PP13 after both IV and SC administration, a two-compartment model with linear elimination was used. Data were collected and calculated in Microsoft Excel, using standard pharmacokinetic equations and simulations. All statistics were performed using GraphPad InStat on Prism (GraphPad Software). 
The absorption half-life $\left(t_{1 / 2}\right.$ abs $)$, elimination half-life $\left(t_{1 / 2}\right)$, elimination constant $(\beta)$, distribution rate constant $(\alpha)$, and total body clearance $\left(C l_{\text {tot }}\right)$ were calculated. Areas under the serum concentration-time curves for both IV (area under the curve $\left.[\mathrm{AUC}]_{\mathrm{IV} 0 \rightarrow \infty}\right)$ and $\mathrm{SC}\left(\mathrm{AUC}_{\mathrm{SC} 0 \rightarrow \infty}\right)$ injections were calculated by the method of trapezoids and presented as $\mathrm{pg}$ PP13 per h/mL (pg.h/mL). Peak serum PP13 concentration $\left(C_{\max }\right)$ and time to reach $C_{\text {max }}\left(t_{\max }\right)$ were determined directly from the individual serum concentration-time curves for the SC administration. Also, the bioavailability of PP13 $\left(F \%=\mathrm{AUC}_{\mathrm{SC}} / \mathrm{AUC}_{\mathrm{IV}} \times 100\right)$ was calculated. All results are presented as mean $\pm \mathrm{SD}$. Harmonic means were calculated for $t_{1 / 2}$ and AUC and presented as mean \pm standard error (SE).

Mann-Whitney $U$ test was used to evaluate the statistical significance of the differences in $t_{1 / 2}$. The AUCs were compared using the independent samples $t$-test. $p<0.05$ was considered statistically significant for all tests. Student's $t$-test was used for data comparison between groups. All values are presented as mean $\pm \mathrm{SD}$, but $t_{1 / 2}$ and $\mathrm{AUC}_{0 \rightarrow 24 \mathrm{~h}}$ are presented as harmonic mean $\pm \mathrm{SE}$.

\section{Results}

\section{IV administration}

Serum concentration-time profiles of PP13, following singledose IV administration of 1.3, 2.6, and $12.8 \mathrm{ng} / \mathrm{kg}$, are shown in Figure 1. The two-compartment model was found to fit best for the majority of animals and used to calculate the pharmacokinetic parameters. The calculated values for AUC were $315 \pm 47,495 \pm 28$, and $1,360 \pm 82 \mathrm{pg} \cdot \mathrm{h} / \mathrm{mL}$ for $1.3,2.6$, and $12.8 \mathrm{ng} / \mathrm{kg}$, respectively. When corrected for the dose

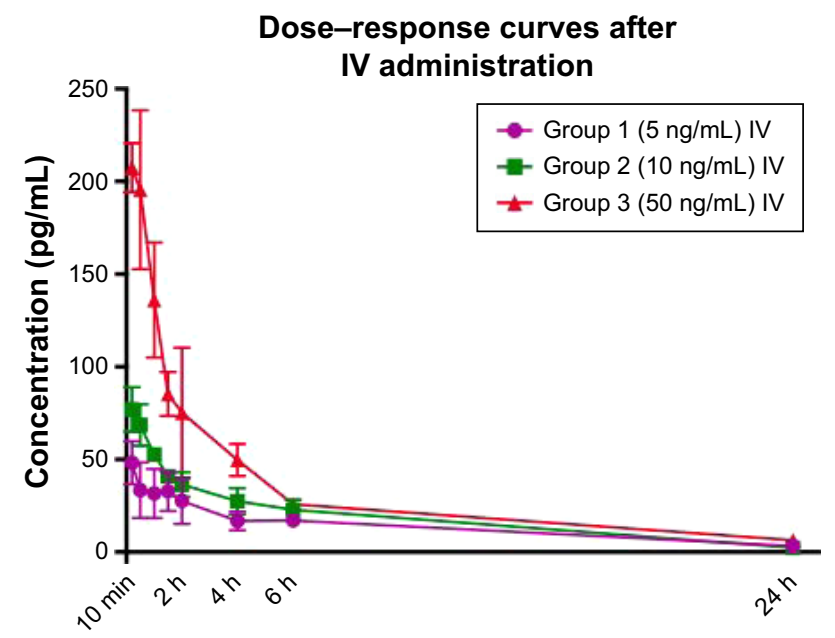

Time points

Figure I Serum concentration-time curves after single IV administration. Notes: Group I: $5 \mathrm{ng} / \mathrm{mL}$ ( $1.3 \mathrm{ng} / \mathrm{kg}), \mathrm{n}=6$; Group 2: $10 \mathrm{ng} / \mathrm{mL}(2.6 \mathrm{ng} / \mathrm{kg}), \mathrm{n}=6$; and Group 3: $50 \mathrm{ng} / \mathrm{mL}(12.8 \mathrm{ng} / \mathrm{kg}), \mathrm{n}=6$. Data are reported as mean \pm SD. Abbreviation: IV, intravenous. given, AUC was equivalent to 246, 193, and $106 \mathrm{pg} \cdot \mathrm{h} / \mathrm{mL}$, showing that there is a drastic significant reduction in AUC with increased dose $(p=0.004)$. Likewise, when volume of distribution (Vd) was compared, there was a significant difference in the value between the lowest and the highest dose $(p<0.001)$. These findings suggest that PP13 binding reached saturation, and thus, it appears that the protein might follow nonlinear pharmacokinetics.

The half-life following IV injection was calculated to be $5.16 \pm 0.97,4.42 \pm 0.77$, and $4.60 \pm 0.09 \mathrm{~h}$ for these three doses, respectively. The clearance for these three doses was found to be $14.0 \pm 1.9,20.3 \pm 3.5$, and $33.5 \pm 2.6 \mathrm{~mL} / \mathrm{kg} / \mathrm{h}$, respectively.

\section{SC administration}

Mean serum concentration-time profiles of PP13 following $\mathrm{SC}$ administration of a single dose $(12.8 \mathrm{ng} / \mathrm{kg})$, in comparison with IV administration, are presented in Figure 2. The corresponding pharmacokinetic parameters were obtained by the two-compartmental analysis. Following SC administration of a single dose at $12.8 \mathrm{ng} / \mathrm{kg}$, the $t_{1 / 2}, t_{1 / 2}$ abs,$C_{\max }$, AUC, and $\mathrm{Cl}$ were $11.4 \pm 1.0 \mathrm{~h}, 4.5 \pm 0.4 \mathrm{~h}, 130 \pm 11 \mathrm{pg} / \mathrm{mL}$, $805 \pm 62 \mathrm{pg} \cdot \mathrm{h} / \mathrm{mL}$, and $60.4 \pm 12.5 \mathrm{~mL} / \mathrm{kg} / \mathrm{h}$, respectively. Based on the equivalent IV dose, the bioavailability $(F)$ was calculated to be $57.1 \% \pm 3.2 \%$.

When the study was performed, all rabbits were clinically healthy and no side effects were observed after the administration of PP13 at any concentration, either after IV $(1.3,2.6$, and $12.8 \mathrm{ng} / \mathrm{kg})$ or after $\mathrm{SC}(12.8 \mathrm{ng} / \mathrm{kg})$ injections. $\mathrm{SC}$ administration was less invasive and easier to manage.

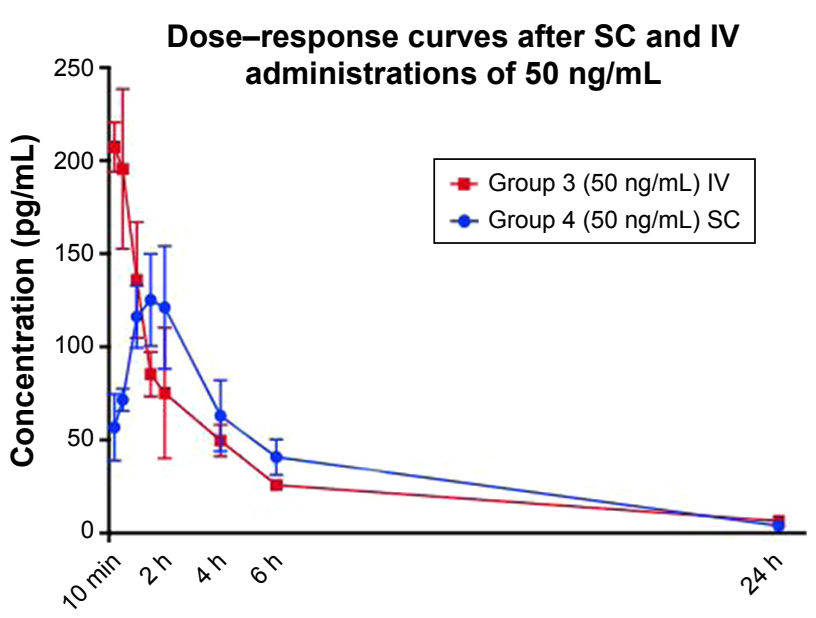

Time points

Figure 2 Serum concentration-time curves after single IV and SC administration of $50 \mathrm{ng} / \mathrm{mL}$ ( $12.8 \mathrm{ng} / \mathrm{kg}), \mathrm{n}=6$.

Note: Data are reported as mean $\pm S D$

Abbreviations: IV, intravenous; SC, subcutaneous. 
Table I Pharmacokinetic parameters for both administration routes based on individual data

\begin{tabular}{|c|c|c|c|c|c|c|}
\hline Parameters & $\begin{array}{l}\text { Group I } \\
\text { (1.3 ng/kg IV) }\end{array}$ & $\begin{array}{l}\text { Group } 2 \\
(2.6 \mathrm{ng} / \mathrm{kg} \mathrm{IV)}\end{array}$ & $\begin{array}{l}\text { Group } 3 \\
(12.8 \mathrm{ng} / \mathrm{kg} \text { IV) }\end{array}$ & $\begin{array}{l}\text { Group } 4 \\
\text { (12.8 ng/kg SC) }\end{array}$ & $\begin{array}{l}\text { p-value (Group } 3 \\
\text { vs Group } 4 \text { ) }\end{array}$ & $\begin{array}{l}\text { P-value } \\
\text { (IV groups) }\end{array}$ \\
\hline$t_{1 / 2}$ (half-life) $(\mathrm{h})^{\mathrm{a}}$ & $5.16 \pm 0.97$ & $4.42 \pm 0.77$ & $4.60 \pm 0.09$ & $11.40 \pm 1.03$ & $0.002 * *$ & 0.29 \\
\hline$t_{1 / 2 \text { abs }}(\mathrm{h})$ & $\mathrm{N} / \mathrm{A}$ & N/A & $\mathrm{N} / \mathrm{A}$ & 4.50 & $\mathrm{~N} / \mathrm{A}$ & $N / A$ \\
\hline$k_{e}\left(h^{-1}\right)$ & $0.15 \pm 0.07$ & $0.16 \pm 0.03$ & $0.15 \pm 0.01$ & $0.06 \pm 0.02$ & $N / A$ & $N / A$ \\
\hline$k_{\text {abs }}\left(\mathrm{h}^{-1}\right)$ & $\mathrm{N} / \mathrm{A}$ & $\mathrm{N} / \mathrm{A}$ & $\mathrm{N} / \mathrm{A}$ & $1.78 \pm 0.34$ & $N / A$ & $\mathrm{~N} / \mathrm{A}$ \\
\hline$\alpha\left(\mathrm{h}^{-1}\right)^{\mathrm{b}}$ & $0.36 \pm 0.14$ & $0.50 \pm 0.13$ & $0.60 \pm 0.23$ & $0.24 \pm 0.09$ & $N / A$ & $N / A$ \\
\hline$\beta\left(\mathrm{h}^{-1}\right)^{\mathrm{b}}$ & $0.09 \pm 0.03$ & $0.13 \pm 0.04$ & $0.04 \pm 0.03$ & $0.14 \pm 0.04$ & $\mathrm{~N} / \mathrm{A}$ & $N / A$ \\
\hline MRT (h) & $1.84 \pm 0.19$ & $1.23 \pm 0.17$ & $0.62 \pm 0.18$ & $\mathrm{~N} / \mathrm{A}$ & $N / A$ & $\mathrm{~N} / \mathrm{A}$ \\
\hline $\mathrm{Vd}_{\mathrm{ss}}(\mathrm{mL} / \mathrm{kg})$ & $25.8 \pm 0.0$ & $25.7 \pm 0.0$ & $14.3 \pm 0.7$ & $\mathrm{~N} / \mathrm{A}$ & $N / A$ & $\mathrm{~N} / \mathrm{A}$ \\
\hline$A \cup C_{0 \rightarrow 24 h}(p g \cdot h / m L)^{a}$ & $315 \pm 47$ & $495 \pm 28$ & $1,360 \pm 82$ & $805 \pm 62$ & $0.001 * *, \mathrm{~b}$ & $N / A$ \\
\hline$C l_{\text {tot }}(\mathrm{mL} / \mathrm{kg} / \mathrm{h})$ & $14.0 \pm 1.9$ & $20.3 \pm 3.5$ & $33.5 \pm 2.6$ & $60.4 \pm 12.5$ & $0.001 * *$ & $0.00 \mathrm{I} * *$ \\
\hline$C_{\max }(\mathrm{pg} / \mathrm{mL})$ & $58.4 \pm 10.9$ & $78.9 \pm 9.6$ & $217.0 \pm 19.3$ & $|30.0 \pm| \mid .4$ & $N / A$ & $N / A$ \\
\hline$t_{\max }(\min )$ & $\mathrm{N} / \mathrm{A}$ & $\mathrm{N} / \mathrm{A}$ & $\mathrm{N} / \mathrm{A}$ & 90 & $\mathrm{~N} / \mathrm{A}$ & $N / A$ \\
\hline $\operatorname{Vd}(\mathrm{L})$ & $110 \pm 13$ & $132 \pm 20$ & $228 \pm 33$ & $\mathrm{I}, 126 \pm 498$ & $N / A$ & $0.000 I^{* *}$ \\
\hline $\mathrm{Vd}_{\mathrm{AUC}}(\mathrm{L})$ & $3.05 \pm 0.74$ & $3.89 \pm 0.93$ & $6.40 \pm 1.94$ & $\mathrm{~N} / \mathrm{A}$ & $N / A$ & $N / A$ \\
\hline AUC/dose $(\mathrm{h} / \mathrm{mL})$ & $0.07 \pm 0.02$ & $0.05 \pm 0.01$ & $0.03 \pm 0.004$ & $0.02 \pm 0.003$ & $N / A$ & $0.004 * *$ \\
\hline$F \%$ & $\mathrm{~N} / \mathrm{A}$ & $\mathrm{N} / \mathrm{A}$ & $N / A$ & $57.1 \pm 3.2$ & $N / A$ & \\
\hline
\end{tabular}

Notes: Each group contained 6 rabbits. a Harmonic mean. ${ }^{b} p$-value was calculated between two groups where the same concentration of the drug was given. $* * p \leq 0.00 \mathrm{I}$. Abbreviations: AUC, area under the concentration-time curve; AUC/dose, AUC corrected for dose; $C_{\text {tot }}$, total body clearance; $C_{\max }$, maximal plasma concentration; $F$ \%, bioavailability; IV, intravenous; $k_{\text {abs }}$, absorption rate constant; $k_{\mathrm{e}}$, elimination constant; MRT, mean resistance time; N/A, not applicable; SC, subcutaneous; $t_{1 / 2}$ abs , absorption half-life; $t_{1 / 2}$, half-life; $t_{\text {max }}$, time to maximum concentration; $\mathrm{Vd}$, volume of distribution; $\mathrm{Vd}_{\mathrm{AUC}}, \mathrm{Vd}$ corrected for $\mathrm{AUC} \mathrm{Vd}_{\mathrm{ss}}$, volume of distribution at steady state; $\alpha$, distribution rate constant; $\beta$, elimination rate constant.

\section{Comparison of parameters between the routes of administration}

The half-life $\left(t_{1 / 2}\right)$ was significantly different between the IV and SC groups receiving the equivalent dose ( $p=0.002)$. AUC and $C l_{\text {tot }}$ were also found to be significantly different $(p<0.001)$. After the SC administration, $\mathrm{PP} 13$ reached the $C_{\max }$ at $90 \mathrm{~min}$, and the bioavailability was calculated to be about $57 \%$, compared with the same dose administered intravenously. The protein was almost completely eliminated from the blood during the next $24 \mathrm{~h}$ in all groups.

The comparison between the different doses (1.3 and 12.8 $\mathrm{ng} / \mathrm{kg}$ ) for IV administration revealed a significant difference between AUC/dose $(p=0.004)$ and $\mathrm{Vd}(p<0.001)$.

The pharmacokinetic parameters of PP13 for both IV and SC administration routes are presented in Table 1.

\section{Discussion}

Rabbits are among the most commonly used animals in preclinical drug development, and it is of utmost importance to understand the differences and similarities in the pharmacokinetic behavior of drug molecules for proper interpretation and integration in the development process for therapies. Therefore, the current study was designed to investigate the pharmacokinetic profile of PP13 in rabbits via two administration routes, and to our knowledge, this study is the first report describing the pharmacokinetics of PP13.
In our previous study conducted in rats, we observed that PP13 was a highly active vasodilator, acting via the vascular endothelium through both eNOS and prostaglandin signaling pathways. ${ }^{21} \mathrm{We}$ have also observed that intraperitoneal delivery of PP13 from osmotic pumps in pregnant rats reduced blood pressure. ${ }^{20}$ The effect of PP13 in both rodents and lagomorphs is considered pharmacological, since both species lack the LGALS13 gene encoding for the protein, which is specific to primates. ${ }^{4,16}$

The absorption kinetics of proteins following SC administration and the distribution of proteins to various tissues are a complex interaction of multiple processes, including absorption by lymphatic capillaries, interstitial transport, specific and nonspecific binding, and presystemic degradation..$^{25,26}$ The structure of the skin as well as the SC space might have an impact on drug absorption as well. ${ }^{26}$

In this study, we observed a relatively short half-life of the protein in all groups. These findings might indicate a rapid elimination of PP13. The rapid elimination could be accounted for by antigen binding to red blood cells ${ }^{14}$ and vascular endothelial blood vessels, ${ }^{21}$ or by tight binding of PP13 (a galectin) to putative tissue receptors (eg, sugar residues of various proteins). ${ }^{27}$

The dose-corrected pharmacokinetic difference between 1.3 and $12.8 \mathrm{ng} / \mathrm{kg}$ dose groups (IV), for both AUC and Vd, presented in Table 1, was unusual and may be explained by the overall effect that the protein might have on blood pressure, ${ }^{20}$ endothelium, and selected arteries and veins. ${ }^{21}$ 
The specific binding site for PP13 has not yet been defined, although, similar to most galectins, PP13 might bind to sugar residues, such as $N$-acetyl-lactosamine and lactose. ${ }^{27}$ Studies from affinity chromatography and mass spectroscopy identified high-affinity binding of PP13 to annexin II and $\beta$ - $\gamma$-actin. ${ }^{1}$ Annexin II is expressed on both activated and resting endothelial cells, ${ }^{28,29}$ and PP13 mainly works on the endothelial layer of arteries. ${ }^{21}$ In addition, the binding can be to sugar residues of the $\mathrm{B}$ and $\mathrm{AB}$ antigens of the $\mathrm{ABO}$ blood groups (oligosaccharides conjugated to cell-surface glycolipids and glycoproteins), as was shown by Than et al. ${ }^{14}$ Such interactions are potentially important regulators for the availability of free PP13 in the blood circulation and have been found to influence the prediction of the risk to develop preeclampsia ${ }^{30}$ and should also be considered for PP13 bioavailability in rabbits, which also carry different blood groups. ${ }^{31}$

In a study by Huppertz et $a 1,{ }^{5}$ in which the serum levels of PP13 were measured throughout pregnancy, the authors reported a 1.4- to 2-fold increase in the blood levels of PP13 in normal pregnancies between the first and third trimesters. The starting concentrations were around $200 \mathrm{pg} / \mathrm{mL}$ in early pregnancy (gestational weeks 5-8) reaching about $400 \mathrm{pg} / \mathrm{mL}$ in late pregnancy (gestational weeks 36-40). In normal pregnancy, maternal blood PP13 level almost completely disappears within few weeks after delivery and placental removal. However, women who later developed preeclampsia had serum levels under $50 \mathrm{pg} / \mathrm{mL}$ in the first trimester, followed by a 7 - to 15 -fold increase of PP13 by week $36 .{ }^{5}$ PP13 serum levels in these women vanished very slowly after delivery and could be determined for 5-6 weeks postpartum and occasionally longer. ${ }^{5} \mathrm{~A}$ recent study by Madar-Sharipo et $\mathrm{al}^{36}$ has shown that combining the presence of the A/A genotype in the -98 site of the PP13 promoter with obesity, African (black) origin, and history of preeclampsia significantly increases the accuracy of predicting the risk of preeclampsia. ${ }^{28}$ The determination of low serum levels of PP13 in early pregnancy contributes to the prediction of preeclampsia as well. Therefore, it is tempting to suggest the possible utility of PP13 as a biomarker for predicting the disorder. ${ }^{4,16,17}$

Immunostaining for PP13 in human placentas showed that it is found in the cytoplasm and brush border membrane of the syncytiotrophoblast and its microparticles (STBMs) that are subsequently shed into the maternal circulation along with their PP13 content. $^{32}$

Based on this study and previous findings, we hypothesize that an elevated amount of PP13 that is released from the placenta into the maternal circulation via STBMs or as free molecules circulates in the maternal blood where it may bind to blood vessels, red blood cells, and potentially to other maternal organs. Hence, the apparent amount of free PP13 that is determined in the blood is just a fraction of the total PP13 released from the placenta.

We propose that the free PP13 determined in the rabbit blood samples may vary due to factors such as 1) high-affinity binding to the $\mathrm{AB}$ and $\mathrm{B}$ antigens of the $\mathrm{ABO}$ blood groups, ${ }^{13}$ 2) specific binding to endothelial binding sites related to the eNOS and prostaglandin ${ }_{2}$ pathways $;{ }^{21}$ and 3) blood vessel vasodilation and hypotension induced by PP $13,{ }^{35}$ which may also influence 4) the peripheral blood return and potentially also the cardiac output. The latter is extremely important when looking at uterine arteries where it has been shown that the Doppler pulsatility index (arterial stiffness and resistance) is higher in patients who subsequently developed preeclampsia. ${ }^{33}$ It was also shown that combining low PP13 with high uterine arteries Doppler pulsatility index can accurately predict the risk to develop preeclampsia. ${ }^{22,33,34}$

If PP13 release from the placental STBMs is considered to be constant in early pregnancy, using a theoretical concentration at steady state $\left(C_{\mathrm{ss}}\right)$ of $300 \mathrm{pg} / \mathrm{mL}$ (corresponding to the average serum levels in normal pregnancies), and data used in this study for allometric scaling between species, then the PP13 dose that is released into the circulation is $1.07 \mathrm{pg} / \mathrm{h}$ in unaffected pregnancies. When correcting the serum concentration of women who are at risk for developing preeclampsia, the loading IV dose would be around $50 \mathrm{pg} / \mathrm{kg}$ of PP13 and $90 \mathrm{pg} / \mathrm{kg}$ if given through SC route. To maintain the correct serum concentration of PP13 throughout pregnancy, based on our data, the dose required would be $10 \mathrm{pg} / \mathrm{kg}$ if given daily through IV route or $20 \mathrm{pg} / \mathrm{kg}$ if given through SC route.

This study has limitations since it was conducted in nonpregnant rabbits, and in addition, as mentioned previously, the LGALS13 gene is expressed in primates but not in rabbits. Therefore, the overall antigen binding of PP13 might differ between species. Galectins can undergo pinocytosis into exosomes that are being released form the placenta. However, this transfer has not yet been elucidated for PP13 outside the placenta. This could be another limitation of our study.

When it comes to the clinical setting of the protein, as described previously, IV administration is unlikely to be used; however, understanding the pharmacokinetic behavior of the drug after IV bolus administration is important. Dose-dependent parameters differ between IV doses. It is suggested that the dose-dependent pharmacokinetics might be explained by the effect PP13 has on the vascular system, 
as reported in our previous studies. ${ }^{20,21,35}$ Thus, when it comes to administration of PP13 to pregnant women, the duration of the drug administration and total volume remain to be tested in greater detail.

Finally, the protein absorption by the lymphatic capillaries was not evaluated here and might be considered as another limiting factor.

\section{Conclusion}

Based on our findings, we hypothesize that the circulating blood levels of PP13 determined by various methods represent only a fraction of what is secreted by the placenta. The rest remains bound to red blood cells, the endothelial layer, and other maternal organs. The study provides important information regarding the basic pharmacokinetic parameters, where some factors were found to be affected by increasing dosage. To estimate the overall systemic distribution of PP13, additional studies are required. In addition, since rabbits are not identical to humans, further studies in humans are needed.

\section{Acknowledgments}

The authors thank Hy Laboratories for providing PP13 to this study through support provided by the European Union through the ASPRE project (\#601852). This study was mainly sponsored by Hananjaehf and the Icelandic Research Fund (Rannís; grant number 163403-052).

\section{Disclosure}

Hamutal Meiri and Sveinbjörn Gizurarson hold a patent for the potential therapeutic use of PP13 in pregnancy complications. Hamutal Meiri is the CEO and Chairman of TeleMarpe Ltd. and is a consultant of Hy Laboratories. The authors report no other conflicts of interest in this work.

\section{References}

1. Than NG, Pick E, Bellyei S, et al. Functional analyses of placental protein 13/galectin-13. Eur J Biochem. 2004;271(6):1065-1078.

2. Barondes SH, Cooper DN, Gitt MA, Leffler H. Galectins. Structure and function of a large family of animal lectins. J Biol Chem. 1994;269(33): 20807-20810.

3. Bohn H, Kraus W, Winckler W. Purification and characterization of two new soluble placental tissue proteins (PP13 and PP17). Oncodev Biol Med. 1983;4(5):343-350.

4. Than NG, Sumegi B, Than GN, Berente Z, Bohn H. Isolation and sequence analysis of a cDNA encoding human placental tissue protein 13 (PP13), a new lysophospholipase, homologue of human eosinophil Charcot-Leyden crystal protein. Placenta. 1999;20(8):703-710.

5. Huppertz B, Sammar M, Chefetz I, Neumaier-Wagner P, Bartz C, Meiri H. Longitudinal determination of serum placental protein 13 during development of preeclampsia. Fetal Diagn Ther. 2008;24(3):230-236.

6. Akolekar R, Syngelaki A, Beta J, Kocylowski R, Nicolaides KH. Maternal serum placental protein 13 at 11-13 weeks of gestation in preeclampsia. Prenat Diagn. 2009;29(12):1103-1108.

7. Naljayan MV, Karumanchi SA. New developments in the pathogenesis of preeclampsia. Adv Chronic Kidney Dis. 2013;20(3):265-270.
8. Sibai B, Dekker G, Kupferminc M. Pre-eclampsia. Lancet. 2005; 365(9461):785-799.

9. Funai EF, Friedlander Y, Paltiel O, et al. Long-term mortality after preeclampsia. Epidemiology. 2005;16(2):206-215.

10. Irgens HU, Reisaeter L, Irgens LM, Lie RT. Long term mortality of mothers and fathers after pre-eclampsia: population based cohort study. BMJ. 2001;323(7323):1213-1217.

11. Chafetz I, Kuhnreich I, Sammar M, et al. First-trimester placental protein 13 screening for preeclampsia and intrauterine growth restriction. Am J Obstet Gynecol. 2007;197(1):e1-e7.

12. Odibo AO, Zhong Y, Goetzinger KR, et al. First-trimester placental protein 13, PAPP-A, uterine artery Doppler and maternal characteristics in the prediction of pre-eclampsia. Placenta. 2011;32(8):598-602.

13. Spencer K, Cowans NJ, Chefetz I, Tal J, Meiri H. First-trimester maternal serum PP-13, PAPP-A and second-trimester uterine artery Doppler pulsatility index as markers of pre-eclampsia. Ultrasound Obstet Gynecol. 2007;29(2):128-134.

14. Than NG, Romero R, Meiri H, et al. PP13, maternal ABO blood groups and the risk assessment of pregnancy complications. PLoS One. 2011; 6(7):e21564.

15. Than NG, Pick E, Bellyei S, et al. Structural and functional characterization of placental protein 13/galectin-13. Placenta. 2004;25(8-9):A52.

16. Than NG, Romero R, Goodman M, et al. A primate subfamily of galectins expressed at the maternal-fetal interface that promote immune cell death. Proc Natl Acad Sci U S A. 2009;106(24):9731-9736.

17. Huppertz B, Meiri H, Gizurarson S, Osol G, Sammar M. Placental protein 13 (PP13): a new biological target shifting individualized risk assessment to personalized drug design combating pre-eclampsia. Hum Reprod Update. 2013;19(4):391-405.

18. Kliman HJ, Sammar M, Grimpel YI, et al. Placental protein 13 and decidual zones of necrosis: an immunologic diversion that may be linked to preeclampsia. Reprod Sci. 2012;19(1):16-30.

19. Than NG, Romero R, Balogh A, et al. Galectins: double-edged swords in the cross-roads of pregnancy complications and female reproductive tract inflammation and neoplasia. J Pathol Transl Med. 2015;49(3): 181-208.

20. Gizurarson S, Sigurdardottir ER, Meiri H, et al. Placental protein 13 administration to pregnant rats lowers blood pressure and augments fetal growth and venous remodeling. Fetal Diagn Ther. 2016;39(1): 56-63.

21. Drobnjak T, Gizurarson S, Gokina NI, et al. Placental protein 13 (PP13)-induced vasodilation of resistance arteries from pregnant and nonpregnant rats occurs via endothelial-signaling pathways. Hypertens Pregnancy. 2017;36(2):186-195.

22. Nicolaides KH, Bindra R, Turan OM, et al. A novel approach to firsttrimester screening for early pre-eclampsia combining serum PP-13 and Doppler ultrasound. Ultrasound Obstet Gynecol. 2006;27(1):13-17.

23. Sammar M, Nisamblatt $S$, Gonen R, et al. The role of the carbohydrate recognition domain of placental protein 13 (PP13) in pregnancy evaluated with recombinant PP13 and the DelT(221) PP13 variant. PLoS One. 2014;9(7):e102832.

24. Cowans NJ, Stamatopoulou A, Jaakohuhta S, Hentunen S, Spencer K. PP13 stability in first trimester maternal serum and whole blood. Prenat Diagn. 2010;30(6):582-585.

25. Kagan L, Gershkovich P, Mendelman A, Amsili S, Ezov N, Hoffman A. The role of the lymphatic system in subcutaneous absorption of macromolecules in the rat model. Eur J Pharm Biopharm. 2007;67(3): 759-765.

26. Richter WF, Bhansali SG, Morris ME. Mechanistic determinants of biotherapeutics absorption following SC administration. AAPS J. 2012;14(3):559-570.

27. Than NG, Balogh A, Romero R, et al. Placental protein 13 (PP13) - a placental immunoregulatory galectin protecting pregnancy. Front Immunol. 2014;5:348.

28. Cesarman GM, Guevara CA, Hajjar KA. An endothelial cell receptor for plasminogen/tissue plasminogen activator (t-PA). II. Annexin IImediated enhancement of t-PA-dependent plasminogen activation. J Biol Chem. 1994;269(33):21198-21203. 
29. Hajjar KA, Jacovina AT, Chacko J. An endothelial cell receptor for plasminogen/tissue plasminogen activator. I. Identity with annexin II. J Biol Chem. 1994;269(33):21191-21197.

30. Watkins WM. The ABO blood group system: historical background. Transfus Med. 2001;11(4):243-265.

31. Cohen C. Blood groups in rabbits. Ann N Y Acad Sci. 1962;97:26-36.

32. Than N, Abdul Rahman O, Magenheim R, et al. Placental protein 13 (PP13/galectin-13) has decreased placental expression but increased shedding and maternal serum concentrations in patients presenting with preterm preeclampsia and HELLP syndrome. Virchows Arch. 2008;453(4):387-400.

33. Plasencia W, Maiz N, Poon L, Yu C, Nicolaides KH. Uterine artery Doppler at $11+0$ to $13+6$ weeks in the prediction of pre-eclampsia. Ultrasound Obstet Gynecol. 2007;30(5):742-749.
34. Audibert F, Boucoiran I, An N, et al. Screening for preeclampsia using first-trimester serum markers and uterine artery Doppler in nulliparous women. Am J Obstet Gynecol. 2010;203(4):e1-e8.

35. Gizurarson S, Huppertz B, Osol G, Skarphedinsson JO, Mandala M, Meiri H. Effects of placental protein 13 on the cardiovascular system in gravid and nongravid rodents. Fetal Diagn Ther. 2013;33(4): 257-264.

36. Madar-Shapiro L, Karady I, Trahtenherts A, et al. Predicting the Risk to Develop Preeclampsia in the First Trimester Combining Promoter Variant -98A/C of LGALS13 (Placental Protein 13), Black Ethnicity, Previous Preeclampsia, Obesity, and Maternal Age. Fetal Diagn Ther. 2018;43:250-265.

\section{Publish your work in this journal}

Drug Design, Development and Therapy is an international, peerreviewed open-access journal that spans the spectrum of drug design and development through to clinical applications. Clinical outcomes, patient safety, and programs for the development and effective, safe, and sustained use of medicines are the features of the journal, which has also been accepted for indexing on PubMed Central. The manuscript management system is completely online and includes a very quick and fair peer-review system, which is all easy to use. Visit http://www.dovepress.com/testimonials.php to read real quotes from published authors.

Submit your manuscript here: http://www.dovepress.com/drug-design-development-and-therapy-journal 